\title{
Kesan Suhu Celupan ke atas Mikrostruktur dan Kekerasan Salutan Aluminium pada Keluli Karbon
}

(Effect of Dipping Temperature on Microstructure and Hardness of Coating Aluminium on Carbon Steel)

\author{
EMEe Marina SALleh, Zaifol SAMSU, Norinsan KAMIL OtHMAN* \& AZMAN JALAR
}

\begin{abstract}
ABSTRAK
Keluli karbon amat mudah terkakis dalam pelbagai persekitaran terutamanya dalam keadaan berudara lembap dan suhu tinggi. Oleh sebab itu, permukaan keluli karbon perlu dilindungi dengan bahan atau logam yang mampu menangani serangan kakisan yang agresif dengan membentuk lapisan oksida dan lapisan antara logam yang bersifat pelindung. Kajian ini dijalankan untuk menentukan mikrostruktur permukaan dan kekerasan salutan aluminium (Al) tulen yang telah dihasilkan melalui teknik celupan panas. Celupan panas dalam leburan Al tulen dilakukan pada suhu berbeza untuk mendapatkan lapisan salutan yang optimum. Keputusan teknik celupan panas menunjukkan dua lapisan utama terhasil iaitu lapisan luar Al dan lapisan dalam aluminit ( $F e-A l)$. Manakala lapisan dalam aluminida terdiri daripada

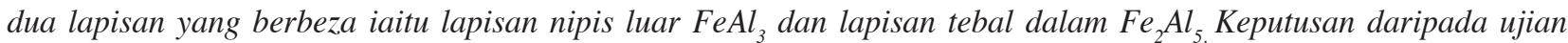
mikrokekerasan Vickers menunjukkan bahawa nilai kekerasan lapisan aluminida meningkat dengan peningkatan suhu leburan Al manakala lapisan Al tidak menunjukkan sebarang perubahan yang ketara.
\end{abstract}

Kata kunci: Aluminida; celupan panas; kekerasan; keluli karbon

ABSTRACT

Carbon steel can easily be corroded in various environments, particularly in wet environment and at high temperature. Thus, the surface of the carbon steel must be protected by a material or metal that can form oxide surface and intermetallic layer that can preserve the carbon steel from aggresive corrosion attack. This study was performed to determine microstructure and hardness of aluminium $(\mathrm{Al})$ coating that produced by hot dipping technique. The hot dipping coating using pure Al was conducted at different molten temperatures in order to attain an optimized coating layer. Two layers were formed on the surface of Al hot dipped carbon steel, the outer Al layer and the inner aluminide layer $(F e-A l)$. The inner aluminide layer consisted of two distinct layers which were thin $\mathrm{FeAl} \mathrm{l}_{3}$ at the outer layer and thicker $\mathrm{Fe}_{2} \mathrm{Al}_{5} \mathrm{on}_{\mathrm{the}}$ inner layer. Microhardness of the aluminide layer values increased with increasing molten Al temperatures used and no apparent change of hardness of Al layer was obtained.

Keywords: Aluminide; carbon steel; hardness; hot dipping

\section{PENGENALAN}

Keluli karbon merupakan salah satu bahan yang menjadi pilihan dalam pelbagai industri kerana sifat mekaniknya yang kuat, mudah dibentuk serta harganya yang murah. Namun begitu, keluli karbon mudah mengalami kakisan serta mudah teroksida apabila didedahkan dalam keadaan tertentu (Bindumadhavan et al. 2000; Cheng \& Wang 2009). Keluli karbon telah digunakan secara meluas dalam industri seperti automotif, minyak dan gas serta pembinaan. Ia menyediakan kos bahan yang murah di samping mempunyai ciri-ciri bahan yang diterima oleh kebanyakan industri (Oni et al. 2008; Springer et al. 2011). Namun begitu, keluli karbon mudah teroksida dengan membentuk lapisan besi oksida yang kurang padat pada permukaan keluli yang menyebabkan ia tidak sesuai digunakan untuk rintangan kakisan (Schmid et al. 2002). Sifat pengoksidan (kakisan) ini telah menyebabkan kemerosotan kepada kekuatan, keupayaan perkhidmatan dan nilai estetika bagi keluli karbon. Oleh sebab itu, keluli karbon perlu ditambah baik dengan menggunakan teknik untuk memastikan ia mampu memberikan rintangan kakisan dalam aplikasi tertentu (Taniguchi et al. 2001).

Kawalan kakisan merupakan aspek yang penting dalam pencegahan kakisan. Terdapat pelbagai kaedah kawalan kakisan iaitu pemilihan reka bentuk yang sesuai, pemilihan bahan yang sesuai, perlindungan anod dan katod, salutan dan penggunaan perencat (Cotell et al. 1999). Kesemua kaedah kawalan kakisan ini bergantung kepada persekitaran yang didedahkan. Salutan aluminium (Al) merupakan satu kaedah kawalan kakisan yang mampu melindungi keluli karbon pada persekitaran biasa dan persekitaran suhu tinggi (Richards et al. 1994). Salutan logam Al merupakan salah satu teknik rawatan permukaan atau pengaloian yang berpotensi memberikan perlindungan kakisan yang baik bagi keluli karbon (Eggeler et al. 1985). Celupan panas $\mathrm{Al}$ merupakan rawatan permukaan yang menghasilkan lapisan pelindung suhu tinggi aluminida pada permukaan keluli karbon untuk meningkatkan 
rintangan pengoksidaan keluli karbon (Cheng \& Wang 2013; Frutos et al. 2009).

Teknik celupan panas Al ini merupakan kaedah yang paling berkesan dan kos terendah untuk mengubah suai permukaan keluli karbon (Wang et al. 2003). Celupan panas Al merupakan teknik salutan yang popular kerana ia melibatkan ikatan kimia secara metalurgi dengan kekuatan ikatan antara salutan dan logam substrat lebih tinggi dihasilkan (Glasbrenner et al. 1997). Fasa antara logam $\mathrm{Fe}-\mathrm{Al}$ yang terbentuk membantu meningkatkan kekuatan ikatan antara salutan dan substrat. Antara faktor yang mempengaruhi pembentukan ikatan antara logam ialah faktor bahan salutan, substrat, permukaan substrat, kadar celupan, suhu dan tempoh celupan (Takata et al. 2014; Yajiang et al. 2002). Namun begitu, suhu dan tempoh celupan memainkan peranan utama dalam pembentukan antara logam kerana mekanisme resapan atom-atom memberi kesan secara langsung dalam pembentukan fasa antara logam (Cheng \& Wang 2011). Melalui kajian ini, suhu celupan telah dipelbagaikan untuk mengkaji mikrostruktur dan kekerasan celupan panas aluminium pada keluli karbon.

\section{BAHAN DAN KAEDAH}

Sampel keluli karbon (AISI 1005) komersial disediakan dalam bentuk segiempat tepat yang bersaiz $20 \times 10 \times 2 \mathrm{~mm}$. Permukaan substrat keluli karbon disediakan melalui proses penjerukan asid dengan larutan 5\% asid hidroklorik $(\mathrm{HCl})$ digunakan untuk membuang lapisan karat pada permukaan. Kemudian, permukaan sampel dibersihkan menggunakan aseton dan air suling untuk menghilangkan bendasing yang masih melekat pada permukaan sampel. Kehadiran bendasing di permukaan sampel seperti minyak, gris dan oksida mampu menurunkan lekatan salutan terhadap substrat. Sampel keluli karbon kemudian dicanai dengan menggunakan kertas silikon karbida ( $\mathrm{SiC}$ ) dengan grit 180 hingga ke grit 1200 untuk mendapat permukaan yang licin supaya keupayaan lekatan salutan dapat dihasilkan. Kemudian sampel ini dicuci secara ultrasonik di dalam aseton untuk menghilangkan kandungan bendasing yang terdapat pada permukaan sampel. Komposisi sampel keluli karbon diuji dengan menggunakan peralatan percikan arka jenis Spektra Analyse Foundry Master. Keputusan analisis adalah seperti di dalam Jadual 1.

Al tulen (99.9\% ketulenan) yang berbentuk butiran dibekalkan oleh Aldrich Chemical Co. Inc. digunakan sebagai bahan utama dalam eksperimen ini. Sebelum proses celupan panas, butiran $\mathrm{Al}$ ini dibersihkan di dalam aseton yang mendidih dan seterusnya dibilas menggunakan air suling untuk menyingkirkan sebarang bendasing yang terbentuk pada permukaan butiran Al. Peleburan Al dilakukan di dalam krusibel grafit yang diletakkan di dalam relau mudah alih berjenama Jelrus. Kemudian, sampel keluli karbon dicelup ke dalam leburan Al tulen pada empat suhu berbeza iaitu $700,750,800$ dan $850^{\circ} \mathrm{C}$.

Pencirian mikrostruktur keratan rentas permukaan dilakukan dengan menggunakan mikroskop imbasan elektron pancaran medan (FE-SEM) jenama model FEI 400. Permukaan sampel dicanai dengan menggunakan kertas pelelas $\mathrm{SiC}$ di atas pencanai Buehler Handdimet dengan grit 180 sehingga 1200 dan digilap menggunakan semburan intan bersaiz butiran $6 \mu \mathrm{m}$ dan diikuti dengan 1 $\mu \mathrm{m}$. Seterusnya, sampel dicuci melalui kaedah ultrasonik. Kemudian, sampel dipunar dengan menggunakan reagen Keller selama 10 s bagi mendapatkan mikrostruktur yang menunjukkan lapisan salutan, antara logam dan substrat keluli karbon. Komposisi kimia larutan reagen Keller yang digunakan ditunjukkan dalam Jadual 2.

Analisis komposisi kimia lapisan salutan ditentukan menggunakan analisis sebaran tenaga sinar-X (EDX) model Genesis 700 dan pengecaman fasa ditentukan menggunakan teknik pembelauan sinar-X (XRD). Mesin pembelauan sinar-X (XRD) daripada jenama PANalytical model PW3040/60 X'Pert PRO menggunakan sumber radiasi $\mathrm{Cu} \mathrm{K} \alpha$ pada voltan $40 \mathrm{kV}$ dan $30 \mathrm{~mA}$. Imbasan ditetapkan

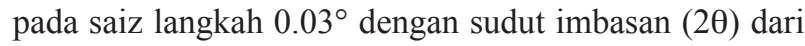
$20^{\circ}$ hingga $90^{\circ}$. Diffraktogram yang diperoleh dikenal pasti dan kandungan fasa yang hadir dianalisis dengan merujuk kepada pengkalan data ICSD (Inorganic Crystal Structure Database) yang menggunakan perisian HighScore Plus Versi 2.2b (2.2.2).

Kekerasan lapisan keratan rentas diukur menggunakan alatan pengujian mikro kekerasan Vickers jenis Shimadzu (HMV-2000). Ujian mikrokekerasan Vickers dilakukan dengan melekukkan sampel yang diuji dengan pelekuk

JADUAL 1. Komposisi kimia bagi kepingan substrat keluli karbon

\begin{tabular}{lcccccccc}
\hline Unsur & $\mathrm{Fe}$ & $\mathrm{C}$ & $\mathrm{Si}$ & $\mathrm{Mn}$ & $\mathrm{P}$ & $\mathrm{Cr}$ & $\mathrm{Mo}$ & $\mathrm{Ni}$ \\
\hline Komposisi (\%bt) & Baki & 0.0472 & 0.0712 & 0.1370 & 0.0136 & 0.0309 & 0.0141 & 0.0350 \\
\hline
\end{tabular}

JADUAL 2. Komposisi kimia larutan punaran reagen Keller

\begin{tabular}{lc}
\hline Komponen & \% kandungan \\
\hline Air & $95 \%$ \\
Asid hidroklorik (Kepekatan 37\%) & $1.5 \%$ \\
Asid hidroflorik (Kepekatan 40\%) & $1.0 \%$ \\
Asid nitrik (Kepekatan 65\%) & $2.5 \%$ \\
\hline
\end{tabular}


intan berbentuk piramid. Beban sebanyak $250 \mathrm{~g}$ dikenakan selama $10 \mathrm{~s}$ pada sampel. Sebanyak 10 bacaan diambil bagi setiap lapisan untuk setiap sampel dan purata bacaan direkodkan.

\section{KEPUTUSAN DAN PERBINCANGAN}

Secara amnya, analisis daripada mikrostruktur keratan rentas menunjukkan bahawa terdapat tiga lapisan utama yang terbentuk melalui proses celupan panas aluminium iaitu lapisan Al, lapisan antara logam dan substrat. Rajah 1 menunjukkan mikrograf keratan rentas permukaan lapisan salutan Al pada substrat keluli karbon yang direndam dalam leburan $\mathrm{Al}$ pada suhu $700^{\circ} \mathrm{C}$ (Rajah $1(\mathrm{a})$ ), $750^{\circ} \mathrm{C}$ (Rajah $1(\mathrm{~b})), 800^{\circ} \mathrm{C}$ (Rajah 1(c)) dan $850^{\circ} \mathrm{C}$ (Rajah 1(d)) dengan masa rendaman selama $3 \mathrm{~min}$. Didapati bahawa berlaku perubahan pada ketebalan lapisan $\mathrm{Al}$ dan lapisan antara logam Fe-Al. Peningkatan ketebalan lapisan Al begitu ketara apabila suhu leburan ditingkatkan daripada 750 kepada $800^{\circ} \mathrm{C}$. Namun begitu, ketebalan lapisan $\mathrm{Al}$ mengalami penurunan apabila suhu leburan mencapai $850^{\circ} \mathrm{C}$. Manakala bagi lapisan antara logam $\mathrm{Fe}-\mathrm{Al}$ pula, peningkatan ketebalan adalah malar pada suhu 700 hingga $750^{\circ} \mathrm{C}$. Walau bagaimanapun, peningkatan ketebalan lapisan antara logam Fe-Al begitu ketara apabila suhu leburan $\mathrm{Al}$ mencapai 800 hingga $850^{\circ} \mathrm{C}$. Lapisan antara logam adalah berbentuk lidah dan ketebalannya bergantung kepada suhu leburan Al. Morfologi lapisan antara logam yang berbentuk lidah ini adalah disebabkan oleh pertumbuhan butiran kolumnar yang tidak sekata (Eggeler et al. 1985; El-Mahallawy et al. 1997). Kewujudan morfologi tidak sekata ini adalah disebabkan oleh resapan secara tidak isotropik (berlakunya orientasi terpilih) bagi struktur ortorombik dengan kepekatan kekosongan yang tinggi berlaku pada paksi C (Bouayad et al. 2003).

Dalam proses celupan panas, Al mula melarut ke dalam substrat keluli yang direndamkan ke dalam leburan. Oleh sebab itu, leburan Al telah meresap ke dalam substrat keluli untuk membentuk lapisan antara logam Fe-Al (Sasaki \& Yakou 2006). Lapisan antara logam yang tidak sekata ini membesar dan bertambah dengan peningkatan suhu dan masa celupan. Apabila masa celupan meningkat, butiran kolumnar berkembang dengan kadar yang sangat cepat ke arah substrat keluli manakala kadar pengembangan dalam sisi butiran kolumnar adalah sangat perlahan. Kajian daripada Cheng dan Wang (2009) telah menunjukkan bahawa pertumbuhan sisi butiran kolumnar yang perlahan telah menyediakan laluan untuk pembentukan kristal nukleus antara logam dalam arah sisi yang menyebabkan pembentukan butiran halus berkelompok yang berbentuk jalur di sekitar puncak gerigi substrat keluli seperti dalam keputusan kajian.

Peningkatan ketebalan antara logam secara beransuransur dengan peningkatan suhu leburan Al telah membawa kepada kewujudan fasa-fasa substrat keluli seperti ferit dan pearlit yang mampu memberi kesan kepada kadar pertumbuhan antara logam (Bouche et al. 1998; Hwang et al. 2005). Fasa-fasa ini muncul di luaran substrat keluli semasa proses celupan panas pada julat suhu tertentu. Oleh sebab itu, peningkatan ketebalan lapisan antara logam pada pelbagai suhu adalah disebabkan oleh fasa ferit yang menggalakkan pertumbuhan lapisan antara logam manakala fasa-fasa pearlit dan austenit telah menghalang pertumbuhan lapisan antara logam (Yousaf et al. 2011).
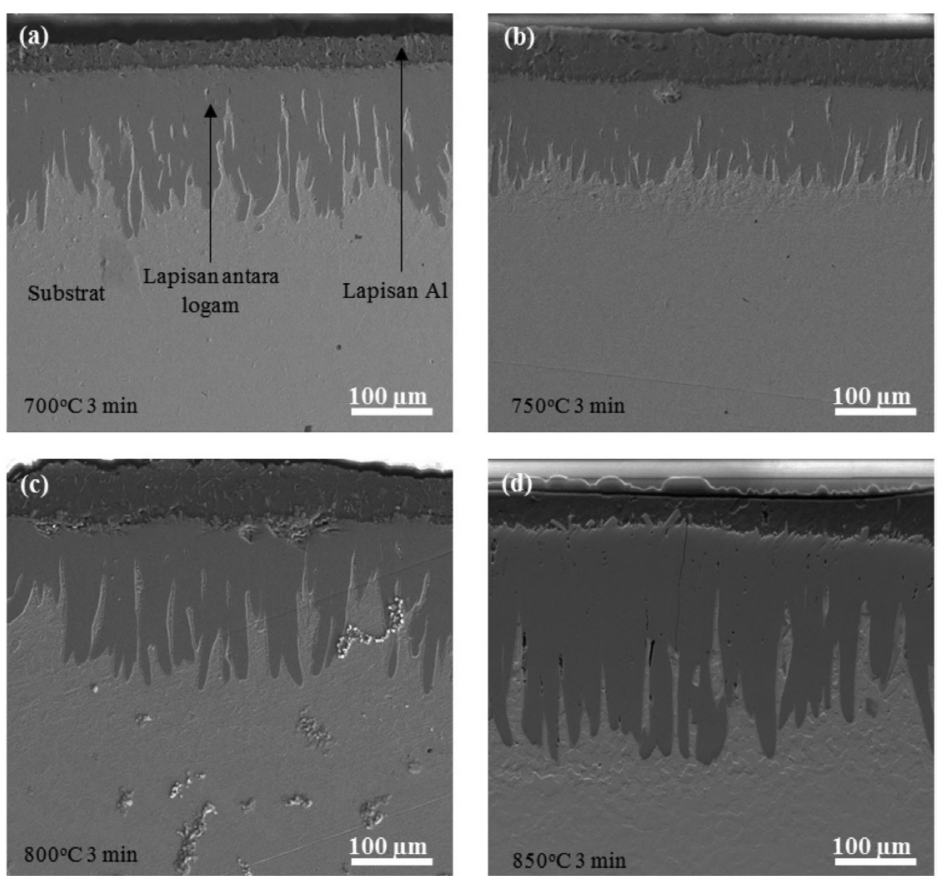

RAJAH 1. Mikrograf keratan rentas permukaan bagi masa celupan 3 min untuk suhu celupan (a) $700^{\circ} \mathrm{C}$, (b) $750^{\circ} \mathrm{C}$, (c) $800^{\circ} \mathrm{C}$ dan (d) $850^{\circ} \mathrm{C}$ 
Walau bagaimanapun, fasa ini tidak memberi kesan kepada morfologi lapisan antara logam.

Proses celupan panas Al dilakukan pada atas suhu yang lebih tinggi daripada takat lebur Al. Pemilihan suhu dan masa celupan yang sesuai merupakan elemen yang penting dalam mengawal kualiti salutan yang dihasilkan. Keputusan daripada Rajah 1 menunjukkan bahawa corak pembentukan kolumnar berbentuk lidah pada suhu $750^{\circ} \mathrm{C}$ dan masa rendaman $3 \mathrm{~min}$ adalah lebih padat dan homogen. Namun begitu, apabila suhu celupan meningkat, didapati bentuk kolumnar antara logam lebih menirus ke arah substrat. Daripada pemerhatian semasa uji kaji, pencelupan pada suhu $700^{\circ} \mathrm{C}$ telah menyebabkan leburan $\mathrm{Al}$ mudah membentuk mendakan di atas permukaan leburan $\mathrm{Al}$ yang menyukarkan proses pencelupan dilakukan dan risiko kerosakan sampel juga tinggi.

Ketebalan lapisan antara logam yang diperoleh melalui mikrograf keratan rentas diukur menggunakan perisian pemprosesan imej. Rajah 2 menunjukkan perubahan ketebalan antara logam bagi suhu 700, 750, 800 dan $850^{\circ} \mathrm{C}$ dengan tempoh pencelupan 3, 6 dan $9 \mathrm{~min}$. Secara keseluruhannya, ketebalan lapisan antara logam meningkat dengan peningkatan masa celupan dan suhu celupan panas. Peningkatan ketebalan antara logam berlaku pada kadar yang malar antara suhu $700^{\circ} \mathrm{C}$ hingga suhu $800^{\circ} \mathrm{C}$ pada tempoh celupan 3 min dengan ketebalan adalah sekitar 76 ke $117 \mu \mathrm{m}$. Namun begitu, kadar peningkatan ketebalan antara logam menjadi begitu ketara apabila suhu celupan meningkat kepada $850^{\circ} \mathrm{C}$ dengan ketebalan lapisan antara logam adalah $271 \mu \mathrm{m}$. Situasi ini juga berlaku pada tempoh celupan yang lain dengan ketebalan lapisan antara logam meningkat dengan ketara apabila suhu celupan mencapai $800^{\circ} \mathrm{C}$ dan $850^{\circ} \mathrm{C}$. Peningkatan suhu serta peningkatan tempoh celupan telah mendorong peningkatan yang ketara dalam pembentukan lapisan antara logam. Fenomena ini menerangkan peningkatan ketebalan lapisan antara logam yang berlaku dengan peningkatan suhu dan tempoh celupan adalah disebabkan oleh pembentukan antara logam $\mathrm{Fe}-\mathrm{Al}$ yang memerlukan atom-atom $\mathrm{Al}$ untuk meresap ke dalam substrat keluli (Chang et al. 2006; Cheng \& Wang 2011).

Rajah 3 menunjukkan mikrograf tipikal keratan rentas sampel celupan panas pada suhu $750^{\circ} \mathrm{C}$ bagi tempoh celupan 3 min dengan kawasan-kawasan analisis sinar-x sebaran tenaga (EDX). Terdapat tiga rantau utama yang dilabelkan sebagai Zon 1 (kawasan laposan salutan Al), Zon 2 (kawasan lapisan antara loga Fe-Al) dan Zon 3 (kawasan subsrat keluli karbon). Setiap zon dianalisis dengan menandakannya sebagai Spektrum 1, 2, 3, 4 dan 5 .

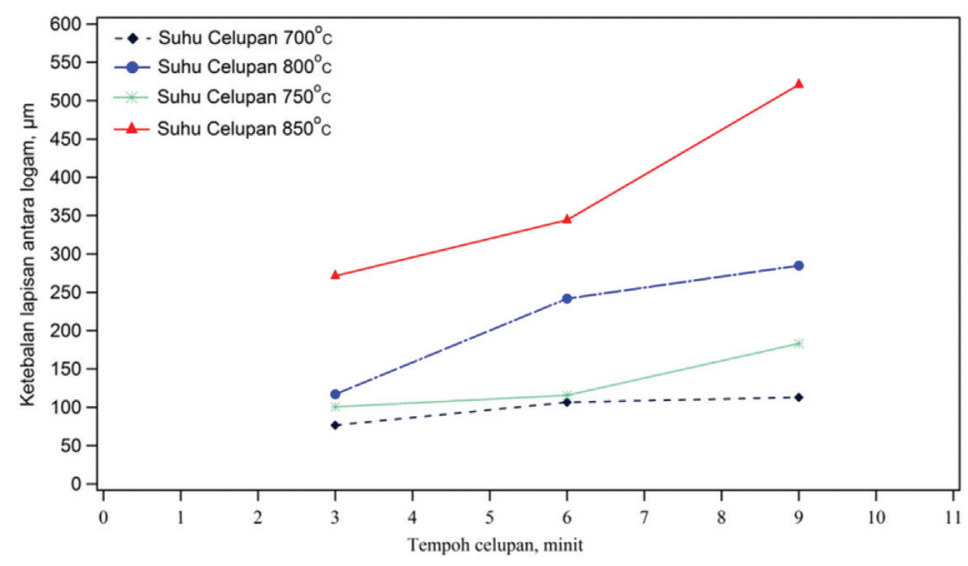

RAJAH 2. Ketebalan lapisan antara logam bagi suhu dan tempoh pencelupan berbeza melalui pengukuran keratan rentas

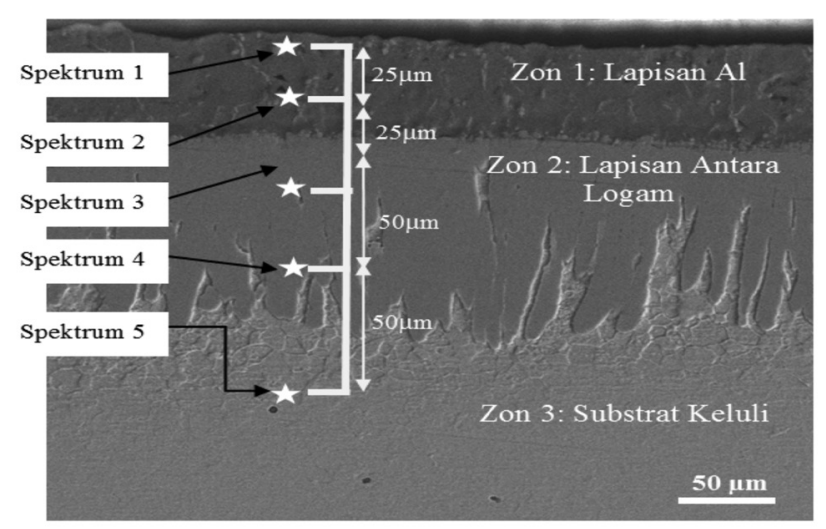

RAJAH 3. Mikrograf keratan rentas permukaan salutan $\mathrm{Al}$ tulen 
Berdasarkan Jadual 3, analisis EDX bagi Zon 1 menunjukkan bahawa lapisan itu mengandungi lapisan aluminium teroksida (Al-O) dan lapisan tebal aluminium tulen (Al). Hal ini dapat dibuktikan dengan kehadiran unsur oksigen (O) sebanyak $6.06 \%$ bt. dalam lapisan paling luar salutan Al. Kewujudan unsur oksida ini adalah keadaan amorfos yang terbentuk melalui peringkat awal pengoksidaan iaitu melalui pendedahan kepada atmosfera atau penganodan (Mondolfo 1976).

Analisis EDX bagi Zon 2 pada Spektrum 3 dan 4 menunjukkan kewujudan fasa antara logam Fe-Al. Tiada sebarang perubahan yang ketara dalam peratusan komposisi berat antara Spektrum 3 dan 4 dengan peratusan berat Al bagi Spektrum 3 dan 4 masing-masing adalah 59.72 dan $56.86 \%$ bt. Keadaan ini menunjukkan bahawa peratusan atom $\mathrm{Al}$ adalah tinggi di kawasan bersempadan dengan lapisan $\mathrm{Al}$ dan semakin berkurangan apabila menghampiri lapisan substrat keluli. Walau bagaimanapun, pengurangan peratusan berat $\mathrm{Al}$ ini tidak akan melebihi jumlah peratusan $\mathrm{Al}$ untuk membentuk lapisan antara logam Fe-Al. Zon 3 mewakili kawasan yang paling dalam dan ia hanya diwakili oleh puncak Fe tanpa kehadiran puncak Al. Fenomena ini menunjukkan bahawa kawasan substrat keluli tersebut tidak ditembusi oleh unsur Al pada kedalaman kurang daripada $50 \mu \mathrm{m}$.

Merujuk kepada gambarajah fasa bagi sistem $\mathrm{Fe}-\mathrm{Al}$ (Kattner \& Burton 1999; Massalski 1990), pada julat peratusan atom Al ini dapat dianggarkan wujudnya fasa-fasa $\mathrm{Fe}_{2} \mathrm{Al}_{5}$ dan kehadiran fasa $\mathrm{FeAl}_{3}$. Keputusan keseluruhan bagi setiap zon menggunakan EDX disokong dengan keputusan analisis XRD dalam Rajah 4. Berdasarkan keputusan analisis XRD dan EDX ini dapat disimpulkan bahawa fasa lapisan antara logam yang terbentuk adalah $\mathrm{Fe}_{2} \mathrm{Al}_{5}$ dan $\mathrm{FeAl}_{3}$. Keputusan ini disokong oleh banyak kajian terdahulu yang mengesahkan kewujudan kedua-dua fasa ini dengan fasa $\mathrm{Fe}_{2} \mathrm{Al}_{5}$ mendominasi lapisan antara logam dan fasa $\mathrm{FeAl}_{3}$ sebagai lapisan nipis yang terbentuk antara fasa $\mathrm{Fe}_{2} \mathrm{Al}_{5}$ dan lapisan $\mathrm{Al}$ (Bouayad et al. 2003; Bouche et al. 1998; Cheng \& Wang 2009; Deqing 2008; Kobayashi \& Yakou 2002; Takata et al. 2014).

Analisis mikro kekerasan dilakukan ke atas sampel salutan $\mathrm{Al}$ pada suhu $700,750,800$ dan $850^{\circ} \mathrm{C}$ bagi tempoh celupan 3, 6 dan 9 min. Kawasan lekukan telah dibahagikan kepada tiga kawasan berbeza iaitu lapisan Al, lapisan antara logam dan lapisan substrat. Rajah 5 menunjukkan nilai kekerasan lebih tinggi dicatatkan pada lapisan antara logam manakala lapisan Al mencatatkan nilai kekerasan paling rendah. Lapisan Al mempunyai nilai kekerasan lebih rendah kerana strukturnya lebih berliang (Wang \& Shi 2004). Peningkatan nilai kekerasan antara logam adalah disebabkan kewujudan fasa antara logam Fe-Al yang lebih keras dan rapuh yang mampu meningkatkan kekerasan lapisan antara logam.

Nilai-nilai kekerasan antara logam pada suhu 700, 750,800 dan $850^{\circ} \mathrm{C}$ masing-masing adalah 1237,1253 , 1324 dan 1368 HV. Nilai-nilai kekerasan ini adalah sejajar dengan keputusan yang diperoleh melalui kajian terdahulu yang mendapati nilai kekerasan sedemikian adalah fasa antara logam Fe-Al (Kobayashi \& Yakou 2002; Pradhan et al. 2014; Wang \& Shi 2004). Peningkatan suhu celupan ini telah meningkatkan nilai mikro kekerasan lapisan antara logam walaupun perubahan itu berlaku pada julat yang kecil. Peningkatan nilai kekerasan secara beransuransur ini disebabkan oleh kewujudan fasa ferit, perlite dan austenit yang lebih banyak semasa proses celupan panas (Frutos et al. 2009; Kobayashi \& Yakou 2002; Samsu et al.2014). Nilai kekerasan lapisan Al dan subsrat tidak menunjukkan sebarang perubahan yang ketara dengan peningkatan suhu dan tempoh celupan. Hal ini menunjukkan peningkatan masa celupan tidak memberi kesan yang besar terhadap kekerasan lapisan salutan Al.

\section{KESIMPULAN}

Salutan Al yang terdiri daripada lapisan Al dan lapisan antara logam $\mathrm{Fe}-\mathrm{Al}$ telah berjaya dihasilkan melalui teknik celupan panas. Lapisan antara logam Fe-Al berbentuk lidah adalah disebabkan oleh pertumbuhan kolumnar yang tidak sekata. Ketebalan lapisan antara logam yang tertinggi dicatat oleh sampel yang dicelup panas pada suhu $850^{\circ} \mathrm{C}$ dan semakin meningkat dengan peningkatan masa celupan. Hasil pencelupan panas Al tulen menunjukkan kewujudan dua lapisan utama iaitu lapisan luar $\mathrm{Al}$ dan lapisan dalam aluminida $\mathrm{Fe}-\mathrm{Al}$ yang terdiri daripada lapisan nipis $\mathrm{Fe}_{3}$ dan lapisan tebal $\mathrm{Fe}_{2} \mathrm{Al}_{5}$. Kekerasan antara logam yang tertinggi adalah $1368 \mathrm{HV}$ yang diperoleh daripada suhu celupan $850^{\circ} \mathrm{C}$. Perbezaan suhu celupan tidak memberikan kesan yang ketara terhadap perubahan kekerasan lapisan salutan Al. Hal ini menunjukkan suhu celupan memberikan kesan yang signifikan terhadap perubahan sifat lapisan salutan Al pada keluli karbon.

JADUAL 3. Analisis keputusan EDX bagi setiap zon dan spektrum

\begin{tabular}{cccccc}
\hline \multirow{2}{*}{ Zon } & Spektrum & \multicolumn{3}{c}{ Unsur (bt\%) } & \multirow{2}{*}{ Fasa } \\
\cline { 3 - 5 } & & $\mathrm{Al}$ & $\mathrm{Fe}$ & $\mathrm{O}$ & $\mathrm{Al}-\mathrm{O}$ \\
\multirow{2}{*}{ Zon 1 } & Spektrum 1 & 93.94 & - & 6.06 & $\mathrm{Al}$ \\
& Spekrum 2 & 100 & - & - & $\mathrm{FeAl}_{3}$ \\
& Spektrum 3 & 59.72 & 40.28 & - & $\mathrm{Fe}_{2} \mathrm{Al}_{5}$ \\
\multirow{2}{*}{ Zon 2 } & Spektrum 4 & 56.86 & 43.14 & - & $\mathrm{Fe}^{2}$ \\
& Spektrum 5 & - & 100 & - & \\
\hline
\end{tabular}



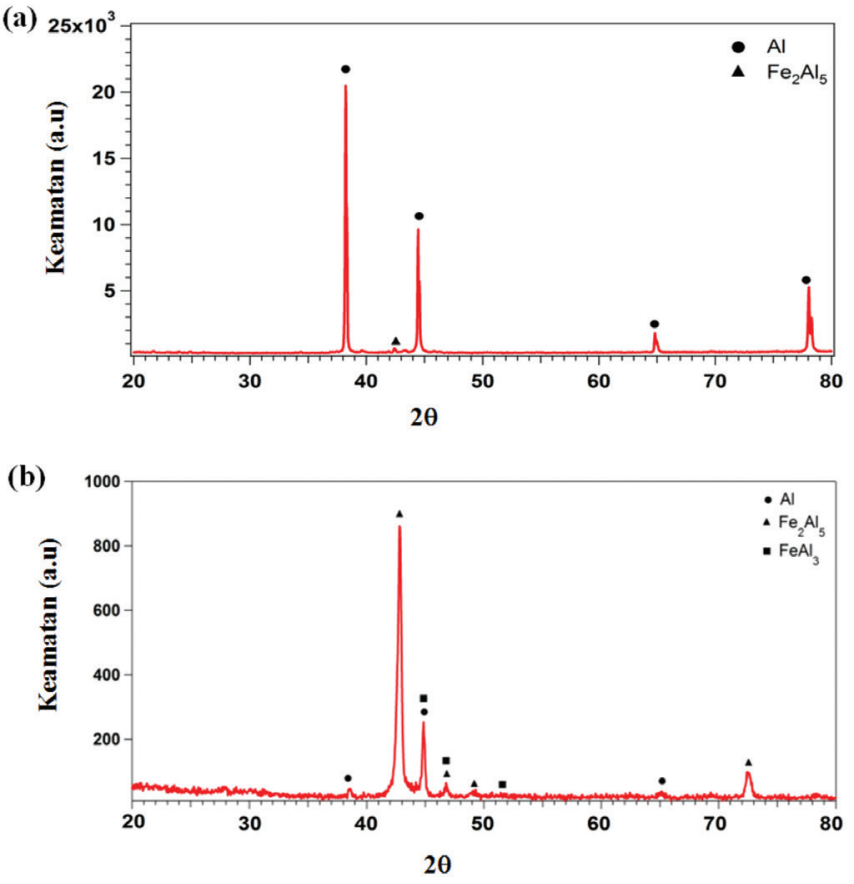

RAJAH 4. Difraktogram pembelauan sinar X bagi permukaan salutan Al tulen yang diperoleh daripada (a) lapisan luar salutan dan (b) lapisan antara logam

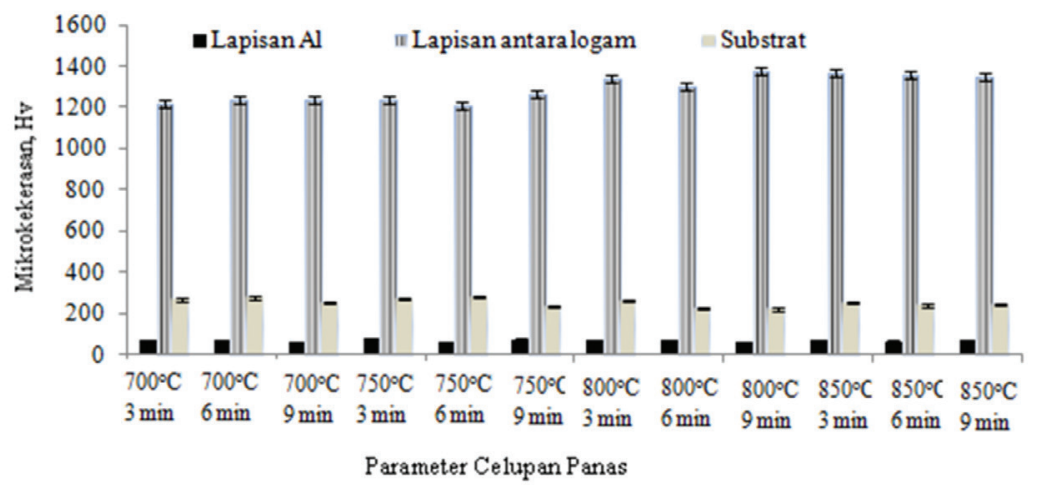

RAJAH 5. Analisis mikrokekerasan Vickers bagi lapisan Al pada suhu dan tempoh celupan yang berbeza

\section{PENGHARGAAN}

Penulis merakamkan penghargaan kepada Universiti Kebangsaan Malaysia (UKM) dan Kementerian Pendidikan Malaysia atas geran penyelidikan (FRGS/1/2016/STG07/ UKM/02/1) dan (FRGSTOPDOWN/2014/ SG06/UKM/03/1).

\section{RUJUKAN}

Bindumadhavan, P.N., Makesh, S., Gowrishankar, N., Keng, W.H. \& Prabhakar, O. 2000. Aluminizing and subsequent nitriding of plain carbon low alloy steels for piston ring applications. Surface and Coatings Technology 127: 251-258.

Bouayad, A., Gerometta, C., Belkebir, A. \& Ambari, A. 2003. Kinetic interactions between solid iron and molten aluminium. Materials Science and Engineering: A 363(1): 53-61.

Bouche, K., Barbier, F. \& Coulet, A. 1998. Intermetallic compound layer growth between solid iron and molten aluminium. Materials Science and Engineering: A 249(1): 167-175.

Chang, Y.Y., Tsaur, C.C. \& Rock, J.C. 2006. Microstructure studies of an aluminide coating on $9 \mathrm{cr}-1$ mo steel during high temperature oxidation. Surface and Coatings Technology 200(22): 6588-6593.

Cheng, W.J. \& Wang, C.J. 2013. High-temperature oxidation behavior of hot-dipped aluminide mild steel with various silicon contents. Applied Surface Science 274: 258-265.

Cheng, W.J. \& Wang, C.J. 2011. Microstructural evolution of intermetallic layer in hot-dipped aluminide mild steel with silicon addition. Surface and Coatings Technology 205(19): 4726-4731.

Cheng, W.J. \& Wang, C.J. 2009. Growth of intermetallic layer in the aluminide mild steel during hot-dipping. Surface and Coatings Technology 204(6): 824-828.

Cotell, C.M., Sprague, J.A. \& Smidt, F.A. 1999. Metal Handbook on Surface Engineering. Material Park, OH: ASM International. 5: 346. 
Deqing, W. 2008. Phase evolution of an aluminized steel by oxidation treatment. Applied Surface Science 254(10): 3026-3032.

Hwang, S.H., Song, J.H. \& Kim, Y.S. 2005. Effects of carbon content of carbon steel on its dissolution into a molten aluminum alloy. Materials Science and Engineering: A 390(1): 437-443.

Eggeler, G., Vogel, H., Friedrich, J. \& Kaesche, H. 1985. Target preparation for the transmission electron microscopic identification of the $\mathrm{Al}_{3} \mathrm{Fe}$ in hot dip aluminized low alloyed steel. Praktische Metallographie 22(4): 163-170.

El-Mahallawy, M.A., Taha, M.A., Shady, A.R., El-Sissi, A.N. \& Attia, W. Reif, 1997. Analysis of coating layer formed on steel strips during aluminising by hot dipping in Al-Si baths. Materials Science and Technology 13(10): 832-840.

Frutos, E., Gonzalez-Carrasco, J.L., Capdevila, C., Jimenez, J.A. \& Houbaert, Y. 2009. Development of hard intermetallic coatings on austenitic stainless steel by hot dipping in an Al-Si alloy. Surface and Coatings Technology 203(19): 2916-2920.

Glasbrenner, H., Nold, E. \& Voss, Z. 1997. The influence of alloying elements on the hot-dip aluminizing process and on the subsequent high-temperature oxidation. Journal of Nuclear Materials 249(1): 39-45.

Kattner, U.R. \& Burton, B.P. 1999. Binary Alloy Phase Diagrams. Material Park, OH: ASM International.

Kobayashi, S. \& Yakou, T. 2002. Control of intermetallic compound layers at interface between steel and aluminum by diffusion-treatment. Materials Science and Engineering: A 338(1): 44-53.

Massalski, T.B. 1990. Binary Alloy Phase Diagram. 2. Material Park,OH: ASM International.

Mondolfo, L.F. 1976. Aluminum Alloy: Structure and Properties. N.A.: Butterworth \& Co Ltd.

Oni, B., Egiebor, N., Ekekwe, N. \& Chuku, A. 2008. Corrosion behavior of tin-plated carbon steel and aluminum in nacl solutions using electrochemical impedance spectroscopy. Journal of Minerals and Materials Characterization and Engineering 7(4): 331.

Pradhan, D., Manna, M., Dutta, M., 2014. Al-Mg-Mn Alloy Coating on Steel with Superior Corrosion Behavior. Surface and Coatings Technology 258: 405-414.

Richards, R.W., Jones, R.D., Clements, P.D. \& Clarke, H. 1994. Metallurgy of continuous hot dip aluminizing. International Materials Review 39(5): 191-212.

Samsu, Z., Othman, N.K., Daud, A.R. \& Daud, M. 2014. Properties and growth rate of intermetallic Al-Fe through hot dipped aluminizing. Advanced Materials Research 980: 3-7.

Sasaki, T. \& Yakou, T. 2006. Features of intermetallic compounds in aluminized steels formed using aluminum foil. Surface and Coatings Technology 201(6): 2131-2139.
Schmid, B., Aas, N., Grong, O. \& Odegard, R. 2002. Hightemperature oxidation of iron and the decay of wüstite studied with in situ esem. Oxidation of Metals 57(1-2): 115130.

Springer, H., Kostka, A., Payton, E.J., Raabe, D., Kaysser-Pyzalla, A. \& Eggeler, G. 2011. On the formation and growth of intermetallic phases during interdiffusion between lowcarbon steel and aluminum alloys. Acta Materialia 59(4): 1586-1600.

Takata, N., Nishimoto, M., Kobayashi, S.\& Takeyama, M. 2014. Morphology and formation of $\mathrm{Fe}-\mathrm{Al}$ intermetallic layers on iron hot-dipped in $\mathrm{Al}-\mathrm{Mg}-\mathrm{Si}$ alloy melt. Intermetallics 54: 136-142.

Taniguchi, S., Hongawara, N. \& Shibata, T. 2001. Influence of water vapour on the isothermal oxidation behaviour of tial at high temperatures. Materials Science and Engineering: A 307(1): 107-112.

Wang, C.J., Lee, J.W. \& Twu, T.H. 2003. Corrosion behaviors of low carbon steel, SUS310 and Fe-Mn-Al alloy with hotdipped aluminum coatings in $\mathrm{NaCl}$-induced hot corrosion. Surface and Coatings Technology 163: 37-43.

Wang, D. \& Shi, Z. 2004. Aluminizing and oxidation treatment of $1 \mathrm{Cr} 18 \mathrm{Ni} 9$ stainless steel. Applied Surface Science 227(1): 255-260.

Yajiang, L., Juan, W., Yonglan, Z. \& Holly, X. 2002. Fine structures in $\mathrm{Fe}_{3} \mathrm{Al}$ alloy layer of a new hot dip aluminized steel. Buletin Material Science 25(7): 635-639.

Yousaf, M., Iqbal, J. \& Ajmal, M. 2011. Variables affecting growth and morphology of the intermetallic layer $\left(\mathrm{Fe}_{2} \mathrm{Al}_{5}\right)$ Materials Characterization 62(5): 517-525.

School of Applied Physics

Faculty of Science and Technology

Universiti Kebangsaan Malaysia

43600 UKM Bangi, Selangor Darul Ehsan

Malaysia

Institute of Microengineering and Nanoelectronic (IMEN)

Universiti Kebangsaan Malaysia

43600 UKM Bangi, Selangor Darul Ehsan

Malaysia

*Pengarang untuk surat-menyurat; email: insan@ukm.my

Diserahkan: 15 September 2017

Diterima: 17 Januari 2018 